\title{
KAJIAN FITOKIMIA EKSTRAK KULIT BIJI KAKAO (Theobroma cacao L.)
}

\author{
Indira Lanti Kayaputri ${ }^{*}$, Debby M. Sumanti, Mohamad Djali, Rossi Indiarto, Dita Listya Dewi \\ Jurusan Teknologi Industri Pangan, Fakultas Teknologi Industri Pertanian Universitas Padjadjaran \\ Jl. Raya Bandung-Sumedang km. 21 Jatinangor, Sumedang 45363, Jawa Barat - Indonesia \\ "Alamat korespondensi: indira.lanti@unpad.ac.id
}

\begin{abstract}
Abstrak: Kulit biji kakao memiliki komponen fitokimia yang diduga berpotensi untuk dimanfaatkan sebagai bahan pengawet alami. Tujuan dari penelitian ini adalah menetapkan komponen fitokimia yang terekstrak dari kulit biji kakao dan mengetahui potensi toksisitas ekstrak kulit biji kakao. Metode penelitian yang digunakan adalah metode eksperimen yang dianalisis secara deskriptif. Hasil penelitian menunjukkan bahwa berdasarkan skrining fitokimia, kulit biji kakao yang diekstrak menggunakan etanol $70 \%$ mengandung alkaloid, flavonoid, tanin, saponin, dan triterpenoid. Analisis fitokimia menggunakan Gas Chromatography-Mass Spectrometry (GC-MS) menunjukkan ekstrak kulit biji kakao mengandung 2,3-butanediol (6,45\%), benzeneacetic acid $(2,33 \%)$, caffeine $(23,51 \%)$, dan theobromine $(65,99 \%)$. Pengujian toksisitas berdasarkan metode Brine Shrimp Lethality Test (BSLT) menunjukkan nilai LC $_{50}$ ekstrak kulit biji kakao adalah 39.595,27 ppm, artinya ekstrak tersebut tidak bersifat toksik terhadap larva Artemia salina.
\end{abstract}

\section{Kata kunci: Kulit Biji Kakao, Theobromine, Fitokimia}

ABSTRACT: Cocoa bean shells contain phytochemical compounds which are potential for their use as natural preservatives. The aim of this study was to determine phytochemical compounds which were extracted from cocoa bean shells and to ascertain the potential toxicity of the extract. The experimental method was used in this research and the data collected were analyzed descriptively. The results of phytochemical screening showed that a cocoa bean shells sample which was extracted with $70 \%$ ethanol contained alkaloids, flavonoids, tannins, saponins, and triterpenoids. Phytochemical analyses using Gas Chromatography-Mass Spectrometry $(G C-M S)$ showed that the cocoa bean shells extract contained 2,3-butanediol $(6.45 \%)$, benzeneacetic acid (2.33\%), caffeine (23.51\%), and theobromine (65.99\%). The examination of toxicity based on the Brine Shrimp Lethality Test (BSLT) assay showed that the $L C_{50}$ of the cocoa bean shells extract was 39,595.27 ppm, which means that the extract was not toxic against Artemia salina.

Keyword: Cocoa Bean Shell, Theobromine, Phytochemical

\section{PENDAHULUAN}

Kakao (Theobroma cacao, L.) merupakan salah satu komoditas perkebunan yang memiliki prospek cerah karena harganya relatif tinggi, mudah dipasarkan serta mempunyai arti ekonomi sebagai penghasil devisa negara (Kuswinanti, 2005). Tanaman kakao dapat tumbuh di sebagian besar wilayah Indonesia terutama Pulau Sulawesi, Pulau Jawa dan Pulau Sumatera (Fowler, 2009). Ketinggian pohon kakao mencapai 12-15 $\mathrm{m}$ dan tumbuh di dataran rendah pada ketinggian kurang dari $700 \mathrm{~m}$ di atas permukaan laut (Beckett, 2004).

Indonesia merupakan negara produsen kakao terbesar ketiga di dunia setelah Pantai Gading dan Ghana (Fowler, 1994). Berdasarkan data dari Direktorat Jenderal Perkebunan, total produksi kakao Indonesia tahun 2009 sebanyak 809.583 ton. Produksi biji kakao kering menghasilkan produk sampingan atau limbah diantaranya kulit buah kakao dan pulp sedangkan pada proses pengolahan biji kakao kering menjadi produk coklat dihasilkan limbah berupa kulit biji kakao. Limbah kulit biji kakao belum dimanfaatkan secara optimal dan nilai ekonomisnya rendah. Sejauh ini limbah kulit biji kakao hanya dimanfaatkan sebagai pakan ternak dan kompos.
Kulit biji kakao adalah kulit tipis, lunak dan agak berlendir yang menyelubungi keping biji kakao. Persentasenya berkisar $10-16 \%$ dari keseluruhan bagian biji kakao kering (Fowler, 2009). Pada proses pengolahan biji kakao menjadi cokelat, kulit biji kakao dipisahkan dari keping bijinya melalui proses winnowing.

Menurut Felita (2012), kulit biji kakao masih mengandung komponen fungsional seperti theobromine, kafein, dan polifenol. Senyawa-senyawa tersebut merupakan komponen fitokimia hasil metabolit sekunder tanaman. Komponen fitokimia dapat diisolasi dari tanaman dengan cara ekstraksi. Salah satu metode ekstraksi yang dapat diterapkan adalah maserasi menggunakan pelarut organik seperti etanol dan aseton.

Berbagai komponen fitokimia pada tanaman diketahui dapat menghambat bakteri patogen (Wendakoon et al., 2012). Beberapa diantaranya flavon, flavonoid dan flavonol yang diketahui secara in vitro menjadi zat antimikroba yang efektif melawan berbagai macam mikroorganisme (Cowan, 1999). Sifat antimikroba pada fitokimia ini diduga berpotensi untuk digunakan sebagai pengawet alami pada bahan pangan. 
Bahan pengawet adalah bahan tambahan pangan yang digunakan untuk memperpanjang daya simpan dengan cara mencegah atau menghambat pertumbuhan mikroorganisme perusak pada bahan pangan. Selama ini banyak bahan pangan yang diawetkan dengan bahan pengawet sintetis. Beberapa bahan pengawet sintetis dipercaya bisa menimbulkan efek negatif bagi kesehatan, seperti memicu pertumbuhan sel kanker akibat senyawa karsinogenik dalam bahan tersebut (Sutomo, 2012). Oleh karena itu diperlukan bahan pengawet alami yang murah, mudah didapat dan memiliki dampak lebih aman terhadap kesehatan. Salah satu alternatifnya adalah dengan memanfaatkan limbah kulit biji kakao. Namun demikian perlu dilakukan penelitian mengenai aspek keamanan kulit biji kakao, ditinjau dari sifat fitokimia dan toksisitasnya.

Hampir semua senyawa bioaktif selalu toksik pada dosis tinggi, oleh karena itu daya bunuh in vivo dari senyawa terhadap organisme hewan dapat digunakan untuk menapis ekstrak tumbuhan yang mempunyai bioaktivitas dan juga memantau fraksi bioaktif selama fraksionasi dan pemurnian (Juniarti et al., 2009). Pengujian toksisitas terbagi menjadi tiga kelompok yaitu pengujian toksisitas akut, subkronis dan kronis. Pengujian toksisitas akut utamanya untuk mencari efek toksik dalam waktu singkat yaitu 24 jam (Harmita \& Radji, 2006). Pengujian ini dianggap sebagai alat yang berguna untuk penilaian awal toksisitas dan telah digunakan untuk mendeteksi toksisitas ekstrak tanaman (Carballo et al., 2002).

Berdasarkan uraian di atas maka perlu dilakukan penelitian untuk mengetahui jenis pelarut yang dapat secara efektif mengekstrak komponen fitokimia dari kulit biji kakao dan menganalisis lebih lanjut komponen fitokimianya secara kualitatif maupun kuantitatif serta potensi toksisitasnya.

\section{BAHAN DAN METODE Bahan percobaan}

Bahan utama yang digunakan pada percobaan adalah kulit biji kakao (Theobroma cacao L.) kering, pelarut etanol p.a., aseton p.a. dan aquabidest. Bahanbahan untuk analisis kualitatif fitokimia adalah aquadest, asam klorida, magnesium, asam sulfat, asam asetat anhidrat, gelatin $2 \%$ serta pereaksi Dragendof. Bahan yang digunakan untuk uji toksisitas adalah larva udang Artemia salina, air, dan garam kristal.

\section{Metode penelitian}

Metode penelitian yang digunakan adalah metode eksperimental yang dianalisis secara deskriptif dengan membandingkan antara dua jenis perlakuan ekstraksi yaitu :

A. ekstraksi menggunakan pelarut aseton-air (7:3, $\mathrm{v} / \mathrm{v})$

B. ekstraksi menggunakan pelarut etanol $70 \%$

\section{Pembuatan ekstrak kulit biji kakao}

Kulit biji kakao kering digiling menggunakan grinder hingga terbentuk serbuk. Serbuk kulit biji kakao diayak menggunakan ayakan tyler ukuran 80 mesh. Serbuk tersebut kemudian ditimbang masingmasing sebanyak 20 g lalu dimasukkan ke dalam erlenmeyer. Pelarut ditambahkan sebanyak masingmasing $200 \mathrm{~mL}$, sehingga rasio antara sampel dan pelarut adalah 1:10, lalu dilakukan maserasi selama 24 jam pada suhu ruang dalam keadaan tertutup dan terhindar dari cahaya langsung. Filtrat dipisahkan dari residunya, kemudian dipekatkan menggunakan alat rotary evaporator pada suhu $45^{\circ} \mathrm{C}$.

\section{Skrining fitokimia}

a) Uji alkaloid (Raaman, 2006)

Ekstrak diaduk dengan penambahan beberapa $\mathrm{mL}$ larutan asam klorida lalu disaring. Filtrat kemudian ditambahkan 1-2 mL pereaksi Dragendorff, terbentuknya endapan kuning menyala mengindikasikan adanya senyawa alkaloid.

\section{b) Uji flavonoid (Shanmugam et al., 2010)}

Ekstrak ditambahkan 8-10 tetes asam klorida dan sejumput serbuk magnesium. Panaskan selama 10-15 menit dan dinginkan, terbentuknya warna merah mengindikasikan keberadaan flavonoid.

c) Uji saponin (Departemen Kesehatan RI, 1989)

Ekstrak dilarutkan dengan $10 \mathrm{~mL}$, air panas dalam tabung reaksi, dinginkan kemudian kocok kuatkuat selama 10 detik, terbentuk buih yang mantap selama tidak kurang dari 10 menit, setinggi $1-10 \mathrm{~cm}$. Buih tidak hilang jika ditambahkan satu tetes asam klorida $2 \mathrm{~N}$.

d) Uji triterpenoid dan steroid (Shanmugam et al., 2010 dengan modifikasi Kokate et al., 2008)

Ekstrak ditambahkan $2 \mathrm{~mL}$ asam asetat anhidrat, kemudian tambahkan $2 \mathrm{~mL}$ asam sulfat dari sisi tabung reaksi. Lapisan coklat yang terbentuk pada pertemuan dua lapisan, lapisan teratas berwarna hijau yang artinya steroid dan terbentuknya warna merah tua yang artinya triterpenoid.

\section{e) Uji tanin (Kurian \& Sankar, 2007).}

Sampel bubuk dipanaskan dalam $100 \mathrm{~mL}$ air selama 30 menit. Ekstrak disaring dan ke dalam $5 \mathrm{~mL}$ larutan tersebut ditambahkan larutan gelatin 2\% sebanyak $2 \mathrm{~mL}$. Endapan putih yang terbentuk mengindikasikan keberadaan tanin.

\section{Analisis GC-MS}

Instrumen yang digunakan adalah GCMSQP2010 Shimadzu. Kolom yang digunakan adalah DB-5MS (kolom non polar). Panjang $=30 \mathrm{~m}$, diameter $=0,25 \mathrm{~mm}$, suhu injektor $250^{\circ} \mathrm{C}$, suhu detektor $280^{\circ} \mathrm{C}$, suhu program $40^{\circ} \mathrm{C} / 2^{\prime}$ kenaikan $10^{\circ} \mathrm{C}$ per menit hingga $280^{\circ} \mathrm{C} / 3^{\prime}$, tekanan $68 \mathrm{Kpa}$, kecepatan alir $0,9 \mathrm{~mL} / \mathrm{menit}$ L. velocity 34,2 . Sampel yang akan 
diuji disaring terlebih dahulu menggunakan kertas saring Whatman no. 40. Sampel kemudian diencerkan 5 kali untuk dibuat sebanyak $1 \mathrm{~mL}$ larutan campuran menggunakan pelarut diklorometana. Sampel diinjeksikan sebanyak $1 \mu \mathrm{L}$.

Brine Shrimp Lethality Test (Meyer et al., 1982 dikutip Juniarti et al., 2009)

Pada Uji Brine Shrimp Lethality Test, diawali dengan penetasan telur udang Artemia salina Leach. Kemudian dilanjutkan dengan persiapan larutan sampel yang akan diuji dalam konsentrasi 10, 100, 200, 500, dan 1000 ppm dalam air laut. Bila sampel tidak larut tambahkan DMSO (Dimethyl sulfoxide).

Pada pengujian toksisitas sebanyak $100 \mu \mathrm{L}$ air laut mengandung 10-12 ekor larva A. salina dimasukkan ke dalam masing-masing vial dan ditambahkan larutan sampel yang akan diuji masingmasing sebanyak $100 \mu \mathrm{L}$, dengan konsentrasi 10, 100, 200, 500, dan 1000 ppm. Setiap konsentrasi dibuat tiga kali pengulangan. Setelah 24 jam, dilakukan perhitungan mortalitas larva yang mati dan masih hidup. Mortalitas dihitung dengan cara :

$$
\text { Mortalitas }=\frac{\text { Akumulasi mati }}{\text { Akumulasi Mati }+ \text { Hidup }} \times 100 \%
$$

Grafik dibuat dengan log konsentrasi sebagai sumbu $\mathrm{x}$ terhadap mortalitas sebagai sumbu y. Suatu zat dikatakan toksik jika LC $_{50}<1000$ ppm untuk ekstrak dan $\mathrm{LC}_{50}<30$ ppm untuk senyawa murni.

\section{HASIL DAN PEMBAHASAN}

\section{Deskripsi karakteristik fisik ekstrak kulit biji Kakao}

Pengamatan karakteristik fisik dilakukan secara deskriptif meliputi warna, aroma dan kekeruhan yang dilakukan perseorangan tanpa uji statistik terhadap ekstrak kulit biji kakao dari semua perlakuan. Hasil pengamatan karakteristik fisik ekstrak kulit biji kakao pada berbagai perlakuan dapat dilihat pada Tabel 1 .

Tabel 1. Deskripsi karakteristik ekstrak kulit biji Kakao

\begin{tabular}{|c|c|c|}
\hline \multirow{2}{*}{$\begin{array}{l}\text { Karakteristik } \\
\text { Fisik }\end{array}$} & \multicolumn{2}{|c|}{ Perlakuan } \\
\hline & $\begin{array}{c}\text { Ekstrak A } \\
\text { aseton-air }(7: 3)\end{array}$ & $\begin{array}{r}\text { Ekstrak B } \\
\text { etanol } 70 \%\end{array}$ \\
\hline Warna & Cokelat & Cokelat \\
\hline Aroma & Khas kakao & Khas kakao \\
\hline Kekeruhan & Keruh $(+++)$ & Keruh $(++)$ \\
\hline Gambar & & \\
\hline
\end{tabular}

Berdasarkan hasil pengamatan, kedua jenis ekstrak memiliki karakteristik fisik yang hampir sama dalam hal warna, aroma dan kekeruhan. Warna ekstrak kulit biji kakao dari setiap perlakuan adalah cokelat. Menurut Fowler (2009), kandungan golongan polifenolik pada kakao bertanggung jawab terhadap warna, memberi rasa sepat dalam mulut dan memiliki manfaat sebagai antioksidan. Biji kakao segar mengandung pigmen berwarna ungu yaitu antosianidin yang akan dioksidasi oleh polifenol oksidase menjadi quinon selama proses fermentasi biji kakao. Quinon dapat membentuk kompleks dengan asam amino dan protein serta mengalami polimerisasi dengan flavonoid untuk membentuk tanin. Tanin tersebut membentuk kompleks dengan protein melalui ikatan hidrogen dan menghasilkan pigmen tak larut air berwarna cokelat yang memberikan warna khas kakao (Afoakwa et al., 2012).

Ekstrak kulit biji kakao menggunakan aseton-air (7:3) lebih keruh dibandingkan dengan ekstrak menggunakan etanol $70 \%$. Hal ini dapat diakibatkan oleh pengaruh kadar tanin yang terkandung di dalam ekstrak tersebut. Menurut Susilawati (2007), pada biji legume semakin gelap warna testa biji menandakan kandungan tanin semakin tinggi. Tanin dapat terekstraksi oleh campuran pelarut organik dan air, terutama lebih efektif menggunakan aseton-air 7:3 dibandingkan dengan pelarut beralkohol, namun aseton dapat menghambat interaksi tanin-protein sehingga menjadi keterbatasan dalam pengujian pengendapan protein oleh tanin (Cannas, 2013).

Ekstrak kulit biji kakao yang dihasilkan pada setiap perlakuan memiliki aroma yang sama yaitu aroma khas kakao. Menurut Misnawi \& Ariza (2011), aroma khas kakao terbentuk oleh reaksi antara prekursor aroma kakao (asam amino bebas dan peptida) dengan gula melalui reaksi Maillard menghasilkan komponen aroma seperti alkohol, eter, furan, tiazol, piron, asam, ester, aldehida, imina, amina, oksazol, pirazin dan pirol. Salah satu senyawa yang berperan dalam aroma khas kakao adalah 2,3butanediol. Senyawa ini terdeteksi oleh GC-MS pada ekstrak kulit biji kakao menggunakan pelarut etanol $70 \%$.

\section{Komponen fitokimia}

Uji kualitatif komponen fitokimia dilakukan untuk mengetahui keberadaan suatu komponen fitokimia dalam ekstrak yang diujikan. Penentuan secara kualitatif dapat dilihat dari perubahan warna atau terbentuknya buih dan endapan jika sampel direaksikan dengan bahan kimia tertentu. Hasil pengujian kualitatif komponen fitokimia ekstrak kulit biji kakao dari berbagai perlakuan disajikan pada Tabel 2.

Hasil pengujian berdasarkan Tabel 2 menunjukkan bahwa ekstrak kulit biji kakao pada setiap perlakuan mengandung komponen fitokimia diantaranya alkaloid, flavonoid, tanin dan saponin dalam intensitas yang berbeda-beda, sedangkan triterpenoid hanya teridentifikasi pada ekstrak menggunakan pelarut etanol $70 \%$.

Menurut Tiwari et al. (2011), etanol lebih mudah berpenetrasi ke membran sel untuk mengekstrak bahan dari tanaman, juga hampir semua komponen 
aktif tanaman yang bersifat antimokroba paling sering diekstrak menggunakan etanol.

Tabel 2. Hasil pengujian kualitatif komponen fitokimia

\begin{tabular}{ccc}
\hline \multirow{2}{*}{ Jenis Pengujian } & \multicolumn{2}{c}{ Hasil Uji } \\
\cline { 2 - 3 } & Aseton-air (7:3) & Etanol 70\% \\
\hline Alkaloid & ++ & ++++ \\
Flavonoid & ++++ & ++++ \\
Tanin & ++ & +++ \\
Saponin & ++++ & ++++ \\
Triterpenoid & - & + \\
Steroid & - & - \\
\hline Keterangan: & & \\
$+:$ Positif lemah, ++: Positif, +++: Positif kuat, \\
$++++:$ Positif kuat sekali
\end{tabular}

Alkaloid: Hasil pengujian alkaloid menunjukkan bahwa kandungan alkaloid pada ekstrak kulit biji kakao menggunakan pelarut etanol $70 \%$ lebih kuat daripada menggunakan pelarut aseton-air (7:3). Menurut Fowler (2009), senyawa jenis golongan alkaloid yang terdapat dalam kulit biji kakao diantaranya kafein dan theobromine.

Terbentuknya endapan dan perubahan warna saat penambahan reagen Dragendorff mengindikasikan keberadaan alkaloid dalam sampel. Reagen Dragendorff mengandung logam-logam bismut nitrat dan kalium iodida. Ion logam $\mathrm{K}^{+}$dari reagen Dragendorff akan membentuk ikatan dengan nitrogen pada alkaloid membentuk kompleks kaliumalkaloid berwarna cokelat muda sampai kuning yang mengendap (Marliana dkk, 2005).

Alkaloid tidak banyak digunakan dalam bidang pangan tapi lebih banyak dimanfaatkan dalam dunia farmakologi/pengobatan. Alkaloid dapat digunakan sebagai pupuk hayati dan sebagai agen kontrol dalam perlindungan tanaman serta menunjukkan sifat antimikroba dan anti parasit (Aniszewski, 2007). Fungsi alkaloid itu sendiri bagi tanaman belum diketahui secara pasti, asumsi yang paling kuat adalah peranannya sebagai pelindung tanaman dari mikroorganisme dan lingkungannya.

Flavonoid: Hasil pengujian flavonoid menunjukkan adanya kandungan flavonoid pada ekstrak kulit biji kakao dari kedua jenis perlakuan dengan intensitas yang sama. Keduanya positif sangat kuat mengandung flavonoid. Terbentuknya warna merah setelah sampel direaksikan dengan asam klorida dan serbuk magnesium mengindikasikan keberadaan flavonoid.

Peran dan kegunaan flavonoid bagi tumbuhan itu sendiri yaitu sebagai pengatur pertumbuhan, fotosintesis, antimikroba, antivirus dan fitoaleksin, sementara bagi manusia flavonoid berperan sebagai antibiotik dan menghambat pendarahan (Susilawati, 2007). Flavonoid juga diketahui secara in vitro menjadi zat antimikroba yang efektif melawan berbagai macam mikroorganisme juga menunjukkan efek penghambatan terhadap beberapa virus (Cowan, 1999).
Tanin: Hasil pengujian tanin menunjukkan adanya kandungan tanin pada ekstrak kulit biji kakao. Sampel yang diekstrak menggunakan etanol $70 \%$ mengandung tanin lebih kuat dibandingkan perlakuan lainnya. Terbentuknya endapan berwarna putih jika direaksikan dengan larutan gelatin menunjukkan adanya tanin dalam sampel. Hal ini berkaitan dengan sifat tanin yaitu dapat mengikat dan mengendapkan protein. Tanin bereaksi dengan gelatin membentuk kopolimer mantap yang tidak larut dalam air (Harborne, 1996).

Sifatnya yang dapat mengikat protein ini pula yang kemudian dapat berpotensi untuk dimanfaatkan sebagai antibakteri. Tanin dapat menghambat pertumbuhan bakteri Staphylococcus aureus, Bacillus subtilis dan Bacillus stearothermophilus melalui mekanisme pengubahan permeabilitas membran sitoplasma (Susilawati, 2007). Senyawa ini dapat mengikat protein lalu menghentikan aktivitas enzim, sehingga metabolisme sel terhenti (Fuller \& Mc Clintock, 1986).

Selain dapat berfungsi sebagai antibakteri, tanin juga memiliki sifat antimikroba terhadap kapang dan khamir serta dapat dimanfaatkan sebagai antioksidan pada lemak dan minyak, zat pewarna, dan antidiare (Susilawati, 2007). Pada aktivitas fisiologis manusia, tanin berfungsi untuk menstimulasi sel fagosit (pertahanan terhadap mikroorganisme) dan antiinfeksi sedangkan pada tanaman, tanin dapat menghambat pertumbuhan serangga (Cowan, 1999). Sifatnya yang dapat mengendapkan protein juga dimanfaatkan dalam industri penyamakan kulit hewan (Harborne, 1996).

Saponin: Berdasarkan hasil pengujian, ekstrak kulit biji kakao dari kedua jenis perlakuan menunjukkan keberadaan saponin dengan intensitas yang sama. Keberadaan saponin ditunjukkan dengan terbentuknya busa saat ekstrak dikocok bersama air di dalam tabung reaksi. Menurut Fuller \& McClintock (1986), kemampuan saponin membentuk busa karena kombinasi sapogenin hidrofobik dan bagian gula hidrofilik.

Beberapa saponin berfungsi dalam pertahanan tanaman terhadap serangan mikroba atau fungi dan melawan virus serta memiliki sifat hemolitik dan beberapa bersifat sitotoksik (Bruneton, 1999). Saponin telah lama digunakan secara tradisional sebagai detergen dan racun ikan (European Food Safety Authority, 2009).

Triterpenoid dan Steroid: Triterpenoid merupakan salah satu golongan terpenoid yang kerangka karbonnya berasal dari enam satuan isoprena, berbentuk kristal, tanpa warna dan tidak bersifat volatil (Harborne, 1996). Triterpenoid yang memiliki aktivitas antimikroba antara lain adalah borneol, sineol, pinene, kamfene dan kamfor, merediol, linaliol, indol dan kadinen. Senyawa ini efektif untuk menghambat pertumbuhan B. subtilis, S. aureus dan 
E. coli (Naufalin dkk., 2005). Steroid tidak terdeteksi pada kedua jenis ekstrak. Menurut Naufalin dkk. (2005) sebagian steroid bersifat nonpolar hingga semipolar, sehingga dalam proses isolasi dapat menggunakan pelarut yang memiliki sifat nonpolar dan semipolar.

Ekstrak kulit biji kakao yang diekstrak menggunakan pelarut etanol $70 \%$ merupakan ekstrak dengan karakteristik fitokimia terbaik dilanjutkan analisis GC-MS. Jenis komponen fitokimia yang terdapat dalam ekstrak kulit biji kakao dapat dilihat pada Tabel 3 .

Berdasarkan Tabel 3, terdapat empat jenis senyawa yang dapat teridentifikasi karena memiliki indeks kemiripan di atas 80. Keempat senyawa tersebut adalah 2,3-butanediol, benzeneacetic acid, kafein dan theobromine. Senyawa kafein dan theobromine merupakan senyawa-senyawa golongan alkaloid sementara 2,3-butanediol merupakan senyawa golongan alkohol.

Benzenacetic acid atau lebih banyak dikenal sebagai phenylacetic acid merupakan senyawa turunan asam amino hidrofobik yaitu fenilalanin. Puncak-puncak lain pada kromatogram selain keempat puncak diatas memiliki indeks kemiripan dibawah 80 setelah dianalisis, artinya senyawa tersebut tidak memiliki kejelasan identitas sehingga tidak dicantumkan pada hasil pengamatan. Setiap senyawa tersebut memiliki waktu retensi yang berbeda-beda.

Senyawa yang memiliki waktu retensi terlama berinteraksi lebih kuat dengan kolom. Kolom (fase diam) yang digunakan pada analisis ini bersifat non polar, sehingga semakin lama senyawa terelusi dari kolom maka senyawa tersebut semakin non polar.

Berat, rumus dan struktur molekul juga dapat didentifikasi berdasarkan spektra massa yang dihasilkan. Persen area didapatkan berdasarkan luas area puncak yang menyatakan banyaknya jumlah suatu senyawa dalam sampel yang diujikan. Semakin besar luas puncak semakin banyak pula kuantitasnya. Senyawa theobromine pada ekstrak kulit biji kakao memiliki persen area tertinggi dibandingkan senyawa yang lain yaitu $65,99 \%$. Kafein memiliki persen area tertinggi kedua setelah theobromine yaitu $23,51 \%$, sedangkan 2,3-butanediol dan benzeneacetic acid memiliki persen area masing-masing sebesar 6,45 dan $2,33 \%$. Persen area menyatakan banyaknya suatu senyawa di dalam ekstrak.

Tabel 3. Data analisis menggunakan GC-MS

\begin{tabular}{|c|c|c|c|c|c|c|c|}
\hline $\begin{array}{c}\text { No. } \\
\text { Puncak }\end{array}$ & Nama Senyawa & RT & SI & BM & $\begin{array}{l}\text { Rumus } \\
\text { Molekul }\end{array}$ & $\begin{array}{c}\text { Area } \\
(\%)\end{array}$ & Struktur Molekul \\
\hline 1 & 2,3-Butanediol & $5,277-5,498$ & 97 & 90 & $\mathrm{C}_{4} \mathrm{H}_{10} \mathrm{O}_{2}$ & 6,45 & \\
\hline 2 & $\begin{array}{l}\text { Benzeneacetic } \\
\text { acid }\end{array}$ & 13,203 & 96 & 136 & $\mathrm{C}_{8} \mathrm{H}_{8} \mathrm{O}_{2}$ & 2,33 & \\
\hline 3 & Kafein & 20,857 & 96 & 194 & $\mathrm{C}_{8} \mathrm{H}_{10} \mathrm{~N}_{4} \mathrm{O}_{2}$ & 23,51 & \\
\hline 4 & Theobromine & $\begin{array}{l}21,621- \\
22,049\end{array}$ & 93 & 180 & $\mathrm{C}_{7} \mathrm{H}_{8} \mathrm{~N}_{4} \mathrm{O}_{2}$ & 65,99 & \\
\hline
\end{tabular}

Keterangan: RT: Retention Time (waktu retensi), SI: Similarity Index (kemiripan), BM: Berat Molekul

Berdasarkan hasil analisis GC-MS, puncak pertama yang dapat diidentifikasi dari ekstrak kulit biji kakao adalah 2,3-butanediol. Menurut Syu (2001), 2,3-butanediol tidak berwarna dan terdapat dalam wujud cair atau kristal padat. 2,3-butanediol merupakan salah satu senyawa organik yang dihasilkan dari proses fermentasi biji kakao. Senyawa ini merupakan salah satu komponen alkoholik yang bertanggung jawab pada karakter aroma khas kakao (Misnawi \& Ariza, 2011). Selain itu, senyawa ini juga ditemukan pada lemak kakao.
Banyak turunan 2,3-butanediol berpotensi digunakan sebagai pelarut, plastik dan sebagai agen anti-freeze (bentuk levo- dari 2,3-butanediol) karena memiliki titik beku yang rendah, selain itu dapat juga dimanfaatkan sebagai flavoring agent pada produk pangan jika dikonversi menjadi diasetil oleh proses dehidrogenasi (Syu, 2001).

Puncak berikutnya yang teridentifikasi setelah 2,3-butanediol adalah benzeneacetic acid atau umumnya lebih dikenal sebagai phenylacetic acid. Senyawa ini berbentuk kristal berwarna putih 
mengkilap serta memiliki aroma seperti madu dan mudah terbakar (Turkington, 2010). Phenylacetic acid merupakan senyawa prekursor bersifat volatil yang ditemukan juga pada biji kakao sebagai turunan dari fenilalanin (Ziegleder, 2009). Senyawa ini berperan penting dalam pembentukan cita rasa kakao.

Senyawa lain yang teridentifikasi dalam ekstrak kulit biji kakao adalah kafein. Kafein merupakan senyawa golongan alkaloid yang secara alami terdapat pada kopi, teh, dan kakao serta dapat ditemukan pada produk-produk cokelat, minuman kakao dan minuman bersoda. Kafein bersifat antimikotik yang dapat menghambat pertumbuhan Aspergillus dan Penicillium sp. serta bersifat antibakteri yang dapat menghambat beberapa jenis bakteri diantaranya $S$. aureus, Salmonella spp., dan E. coli (Buffo \& Holley, 2006).

Puncak terakhir yang dapat diidentifikasi oleh GC-MS adalah senyawa theobromine. Senyawa ini merupakan salah satu jenis senyawa golongan alkaloid yang menyebabkan rasa pahit pada biji kakao (Ziegleder, 2009). Menurut Buffo dan Holley (2006), theobromine yang terdapat pada teh dan kakao dianggap berperan sebagai agen antimikroba. Theobromine seringkali dilaporkan bersifat toksik terhadap hewan seperti anjing, namun tidak terhadap manusia. Theobromine lebih berbahaya bagi anjing daripada manusia karena anjing tidak dapat memetabolisme zat ini secepat manusia. Meskipun theobromine dianggap sebagai zat beracun, ia dilaporkan memiliki beberapa aktifitas farmakologis seperti anti kanker, diuretik, stimulan kardiak, hypocholesterolemic, smooth-muscle relaxants, vasodilator asma dan koroner (Bispo, 2002 dikutip Hartati, 2012).

Menurut Minifie (1989), kulit biji kakao mengandung sejumlah theobromine, kafein dan tannin. Berdasarkan hasil analisis menggunakan alat GC-MS tidak menunjukkan adanya senyawa tannin. Kemungkinan karena tannin tidak bersifat volatil sehingga kurang sesuai dengan kondisi alat GC-MS, selain itu tanin juga sensitif terhadap temperatur dan cahaya (Seigler, 1998). Menurut Hendayana (2010), syarat sampel yang digunakan dalam analisis kromatografi gas adalah sampel yang mudah menguap dan memiliki stabilitas termal, suhu injeksi sekitar $50^{\circ} \mathrm{C}$ di atas titik didih sampel dan jika sampel rusak pada suhu tersebut maka tidak dapat dianalisis dengan teknik kromatografi gas. Komponen yang kurang volatil dan kurang memiliki stabilitas termal memerlukan proses derivatisasi terlebih dahulu sebelum dianalisis menggunakan GC-MS untuk meningkatkan pendeteksian, respon detektor, stabilitas komponen, efisiensi analisis, dan keseimbangan bentuk puncak (Sellers, 2010).

Nilai $\mathbf{L C}_{\mathbf{5 0}}$. Pengujian toksisitas terhadap ekstrak kulit biji kakao dilakukan menggunakan metode Brine Shrimp Lethality Test (BSLT) dengan larva Artemia salina sebagai hewan uji. Berdasarkan hasil pengujian, semakin tinggi konsentrasi ekstrak kulit biji kakao, semakin besar pula persentase kematian larva udang. Cara kerja senyawa-senyawa tersebut adalah dengan bertindak sebagai stomach poisoning atau racun perut.

Suatu zat dikatakan aktif atau toksik bila nilai $\mathrm{LC}_{50}<1000$ ppm untuk ekstrak dan $\leq 30$ ppm untuk suatu senyawa (Meyer et al., 1982 dikutip Juniarti et al., 2009). Hasil perhitungan rata-rata $\mathrm{LC}_{50}$ menunjukkan bahwa nilai rata-rata $\mathrm{LC}_{50}$ ekstrak kulit biji kakao adalah 39.595,27 ppm, artinya ekstrak tersebut tidak bersifat toksik bagi larva Artemia salina.

Jika hasil uji BSLT menunjukkan bahwa ekstrak tumbuhan bersifat toksik $\left(\mathrm{LC}_{50}<1000 \mathrm{ppm}\right)$ maka dapat dikembangkan untuk obat alternatif antikanker. Menurut Fowler (2009), kulit biji kakao dapat dimanfaatkan sebagai substitusi pada serbuk kakao untuk menambah kandungan seratnya. Ekstrak kulit biji kakao dapat dimanfaatkan sebagai antimikroba karena kandungan komponen fitokimianya. Kandungan komponen fenoliknya seperti tanin dan flavonoid berpotensi sebagai sumber antioksidan alami (Sartini dkk, 2009).

\section{KESIMPULAN}

Pelarut etanol $70 \%$ lebih efektif dalam mengekstrak komponen fitokimia dari kulit biji kakao daripada menggunakan pelarut aseton-air (7:3, v/v). Berdasarkan hasil skrining fitokimia, ekstrak kulit biji kakao fraksi etanol $70 \%$ mengandung alkaloid, flavonoid, tanin, saponin, dan triterpenoid. Pengamatan menggunakan GC-MS menunjukkan terdapat 4 jenis senyawa yang terkandung dalam ekstrak kulit biji kakao yaitu 2,3-butanediol $(6,445 \%)$, benzeneacetic acid (2,33\%), kafein $(23,51 \%)$, dan theobromine $(65,99 \%)$. Ekstrak kulit biji kakao tidak berpotensi toksik terhadap larva Artemia salina karena memiliki nilai $\mathrm{LC}_{50}>1000 \mathrm{ppm}$, yaitu 39.595,27 ppm.

\section{UCAPAN TERIMA KASIH}

Ucapan terima kasih disampaikan kepada Universitas Padjadjaran yang telah mendanai penelitian ini, rekan-rekan Tim Peneliti Kulit Biji Kakao, dan mahasiswa yang telah membantu dalam kelancaran penelitian ini.

\section{DAFTAR PUSTAKA}

Abdullah, K. (2003). Postharvest Technology of Cocoa. Dalam : Chakraverty, A., Mujumdar, A.S., Raghavan, G.S.V. \& Ramaswamy, H.S. Handbook of Postharvest Technology. Marcel Dekker Inc., New York, NY.

Afoakwa, E.O., Quao, J., Takrama, F.S., Budu, A.S. \& Saalia, F.K. (2012). Changes in total polyphenols, $o$-diphenols and anthocyanin concentrations during fermentation of pulp preconditioned Cocoa (Theobroma cacao) beans. 
International Food Research Journal, 19(3): 1071-1077.

Aniszewski, T. (2007). Alkaloids-Secrets of Life. Elsevier, Oxford.

Baker, C., Kill, R.C., \& Ranken, M.D. (1997). Food Industries Manual. Blackie Academic \& Professional, London.

Beckett, S.T. (2004). The Science of Chocolate. The Royal Society of Chemistry, Cambridge.

Bruneton, J. (1999). Pharmacognocy, Phytochemistry Medicinal Plants. Lavoisier Publishing Inc., Paris.

Buffo, R.A. \& Holley, R.A. (2006). Effects of Food Processing on Disease Agents. Dalam: Riemann, H.P. \& D.O. Cliver. Foodborne Infections and Intoxications, Elsevier, Amsterdam.

Cannas, A. (2013). Tannins: Fascinating but Sometimes Dangereous Molecules. Available at: www.ansci.cornell.edu (diakses pada 25 September 2013).

Carballo, J.L., Hernandez-Inda, Z.L., Perez, P. \& Garcia-Gravalos, M.D. (2002). A comparison between two Brine Shrimp assays to detect in vitro cytotoxicity in marine natural products. BMC Biotechnology, 2(17), 1-5.

Cowan, M.M. (1999). Plant products as antimicrobial agents. Clinical Microbiology Reviews, 12(4), 564-582.

Das, K., Tiwari, R.K.S. \& Shrivastava, D.K. (2010). Techniques for evaluation of medicinal plant products as antimicrobial agent: Current methods and future trends. Journal of Medicinal Plants Research, 4(2), 104-111.

Departemen Kesehatan R.I. (1989). Materia Mediaka Indonesia. Depkes RI, Jakarta.

European food safety authority (2009). Saponin in Madhuca longifolia L. as undesirable substances in animal feed. The EFSA Journal, 979, 1-36.

Fauzia \& Larasati, A. (2008). Uji efek ekstrak air dari daun Avokad (Persea gratissima) terhadap Streptococcus mutans dari saliva dengan kromatografi lapisan tipis (TLC) dan konsentrasi hambat minimum (MIC). Majalah Kedokteran Nusantara, 41(3), 173-178.

Gupta, A., Naraniwal, M., \& Kothari, V. (2012). Modern extraction methods for preparation of bioactive plant extracts. International Journal of Applied and Natural Science, 1(1), 8-26.

Hartati, I. (2012). Prediksi kelarutan theobromine pada berbagai pelarut menggunakan parameter kelarutan Hidelbrand. Momentum, 8(1), 11-16.

Johnson, I. \& Williamson, G. 2003. Phytochemical Functional Foods. Woodhead Publishing Limited, Cambridge.

Juniarti, Osmeli, D., \& Yuhernita, (2009). Kandungan senyawa kimia, uji toksisitas (Brine Shrimp Lethality Test) dan antioksidan (1,1-diphenyl-2pikrilhydrazyl) dari ekstrak daun Saga. Makara Sains, 13(1), 50-54.
Kokate, C.K., Purohit, A.P. \& Gokhale, S.B. (2008). Pharmacognosy. Nirali Prakashan, Maharashtra.

Kurian, A. \& Sankar, M.A. (2007). Medicinal Plants: Vol. 02. Horticulture Science Series. New India Publishing Agency (NIPA), New Delhi.

Kuswinanti, T. (2005). Pengaruh lama penyimpanan terhadap keberadaan Cendawan dan Bakteri pasca panen pada biji Kakao. J. Sains \& Technology, 5(3), 154-158.

Lambert, J.P. (2009). Flavour Development in Cocoa And Chocolate. Dalam: Beckett, S.T. Industrial Chocolate Manufacture and Use. WileyBlackwell, Chichester.

Marliana, S.D., Suryanti, V. \& Suyono, (2005). Skrining fitokimia dan analisis kromatografi lapis tipis komponen kimia buah Labu Siam (Sechium edule Jacq. Swartz.) dalam ekstrak etanol. Biofarmasi, 3(1), 26-31.

McMaster, M.C. (2008). GC/MS a Practical User's Guide. John Wiley \& Sons, Inc., Hoboken, NJ.

Minifie, B.W. (1989). Chocolate, Cocoa and Confectionary. Van Nostrand Reinhold, New York, NY.

Misnawi \& Ariza, B.S.T. (2011). Use of gas chromatography-olfactometry in combination with solid phase micro extraction for Cocoa liquor aroma analysis. International Food Research Journal, 18, 829-835.

Muharrami, L.K. (2011). Penentuan kadar kolesterol dengan metode kromatografi gas. Agrointek, 5(1), 28-32.

Naufalin, R., Jenie, B.S.R., Kusnandar, F., Sudarwanto, \& M., Rukmini, H. (2005). Aktivitas antibakteri ekstrak bunga Kecombrang terhadap bakteri patogen dan perusak pangan. Jurnal Teknotan dan Industri Pangan, 16(2), 119-125.

Organisation for Economic Co-operation and Development, (1999). Acetone: SIDS Initial Assessment Report (SIAR) for the 9th SIAM. UNEP Publications.

Organisation for Economic Co-operation and Development, (2004). Ethanol: SIDS Initial Assessment Report for SIAM 19. UNEP Publications.

Pisutthanan, S., Plianbangchang, P., Pisutthanan, N., Ruanruay, S. \& Muanrit, O. (2004). Brine Shrimp lethality activity of Thai medicinal plants in the family Meliaceae. Naresuan University Journal, 12(2), 13-18.

Raaman, N. (2006). Phytochemical Techniques. New India Publishing Agency, New Delhi.

Sartini, M., Djide, N. \& Alam, G. (2009). Ekstraksi komponen bioaktif dari limbahk kulit buah Kakao dan pengaruhnya terhadap aktifitas antioksidan dan antimikroba. Journal of Traditional Medicine, 14(47).

Scalbert, A. (1992). Quantitative Methods for the Estimation of Tannins in Plant Tissues. Dalam: Hemingway, R.W. \& Laks, P.E. Plant 
Polyphenols : Synthesis, Properties, Significance. Plenum Press, New York, N.Y.

Seigler, D.S. (1998). Plant Secondary Metabolism. Kluwer Academic Publishers, Dordrecht.

Shanmugam, S., Kumar, T.S. \& Selvam, K.P. (2010). Laboratory Handbook on Biochemistry. PHI Learning Private Limited, New Delhi.

Sirait, M. (2007). Penuntun Fitokimia Dalam Farmasi. Penerbit ITB, Bandung.

Sparkman, O.D., Penton, Z.E. \& Kitson, F.G. (2011). Gas Chromatography and Mass Spectrometry. Academic Press, Oxford.

Susilawati, Y. (2007). Flavonoid Tanin-Polifenol. Universitas Padjadjaran, Jatinangor-Indonesia.

Syu, M.J. (2001). Biological production of 2,3butanediol. Applied Microbiology and Biotechnology, 55, 10-18.

Tiwari, P., Kumar, B., Kaur, M., Kaur, G. \& Kaur, H. (2011). A review: Phytochemical screening and extraction. Internationale

Pharmaceutica Sciencia, 1(1): 98-106.
Turkington, R. (2010). Chemical Used for Illegal Purposes. John Wiley \& Sons, Inc., Hoboken, NJ.

Van Stappen, G. (1996). Artemia. Dalam: Lavens, P \& Sorgeloos P. (1996). Manual on The Production and Use of Live Food For Aquaculture. Food and Agriculture Organization, Roma.

Von Bibra, B.E. (1995). Plant Intoxicants: A Classic Text on The Use of Mind-Altering Plants. Healing Arts Press, Vermont.

Wendakoon, C., Calderon, P., \& Gagnon, D. (2012). Evaluation of selected medicinal plants extracted in different ethanol concentrations for antibacterial activity against human pathogens. Journal of Medicinally Active Plants, 1(2): 6068.

Wood, G.A.R. \& Lass, R.A. (1985). Cocoa. Longman Inc., New York, NY.

Ziegleder, G. (2009). Flavour Development in Cocoa and Chocolate. Dalam: Beckett, S.T. Industrial Chocolate Manufacture and Use. WileyBlackwell, Chichester. 